\title{
ORGANISATION DESIGN AND THE ROLE OF ICT: NEGATIVE EFFECTS OF WORKING FROM HOME DURING THE CORONAVIRUS PANDEMIC
}

\begin{abstract}
Ernad Kahrović ${ }^{1}$, Emina S. Kahrović ${ }^{2}$
1, 2 Department of Economics Sciences, State University of Novi Pazar

Corresponding: ekahrovic@np.ac.rs ${ }^{1}$

Review article

Received: 20.02.2021; Accepted: 15.04.2021

Abstract. The goal of the paper is to point to the role and importance of organisation design as a tool for strategy implementation, together with a dominant role of technology in shaping the design. Namely, the development of modern information and communication technology (ICT) is accompanied by the creation of new organisational forms, which enable the management and employees to carry out a significant portion of work from home. The central focus of this paper is the impact of technology on the creation of new forms of design, with a virtual organisation taking up a particularly prominent position. We underline the fact that among many changes that the coronavirus pandemic has produced in everyday life, working from home can be considered as the most drastic one; hence, its harmful effects are underscored, such as those relating to negative psychological effects, anxiety disorders, health issues, job loss, decreased efficiency and reduced satisfaction of the employees.
\end{abstract}

Keywords: organisation design, information technology, coronavirus.

\section{Introduction}

Until the 1980 s, it was not too complicated to design an efficient and effective organisation since the economic conditions were stable, and the environment predictable. In the last forty years, business environment conditions have started to take on completely new qual- ities, which consequently stimulated a growing interest in organisation design. Namely, organisation design has become a major factor in the success of modern businesses, [Galbraith, 2012; Burton, 2013; Daft, 2015] and it was particularly popularised in the 1960s when the leading companies faced radical changes in the environment and 
Kahrović E. et al., Organisation Design and the Role of ICT: Negative Effects of Working from Home During the Corona Virus Pandemic

were forced to change the business strategy and its organisation along with it. [Janićijević et al., 2019]

In order to support their strategy implementation and direct their employees towards their realisation, managers need to select an appropriate organisation design, [Daft, 2015] whose function is to adjust the operation of the entire organisation to the vision statement, [Irwin \& Cichocki, 2011] whereby strategy represents a goal, and design a means to achieve the goal. [Burton et al., 2006] The way in which organisation design of a business will be constituted is dependent on many factors, and those most frequently occurring in literature are environment, business size and life cycle, strategy, technology, and more recently organisational culture. When authors in the field of organisation design started to investigate the impact of various factors on organisation design, they employed the one-factor approach, and underlined therein the influence of individual factors on organisation design process. Lawrence and Lorsch, as well as Katz and Kahn underscored the significance of environment, [Lawrence \& Lorsch, 1967; Katz \& Kahn, 1978] Chandler emphasised the importance of business strategy, [Chandler, 1962] Woodward pointed to the impact of technology, [Woodward, 1965] while the research of
Pugh and his associates demonstrated the importance of business size on its design. [Pugh \& Hickson, 1993] In contrast to the abovementioned authors, Mintzberg was the first to use a multifactor approach to evaluate the influence of environment, size and life cycle, strategy, and technology on organisation design. [Mintzberg, 1979] Moreover, according to Daft, situational factors affecting the shape of an organisation are strategy, environment, size, life cycle, and culture. [Daft, 2015]

Technology has been one of the most influential factors in the organisation design process since the 1960s, [Woodward, 1965; Thompson, 1967; Perrow, 1967] whose influence is becoming more and more overwhelming nowadays. First and foremost, technology facilitates the automation of work processes and their faster, better quality and more efficient perfor-mance. With the development of modern information and communication technology, new organisational forms have occurred, which enable the management and employees to carry out a significant portion of work from home. The focal point of this paper is the impact of technology on the creation of new forms of design, among which virtual organisation holds a special place. Likewise, we also highlight the fact that one of the most drastic 
life changes that the coronavirus pandemic brought in 2020 was working from home; hence, its negative effects are underlined herein.

The paper is structured in the following way. After the Introduction, Part 2 deals with the influence of information and communication technology on organisation design of a company, together with the occurrence of new forms of design. Part 3 covers the negative effects of working from home during the coronavirus pandemic. Finally, the Conclusion considers some important issues relating to how working from home may be improved.

\section{The impact of technology on organisation design: New forms of design}

One of the most relevant factors affecting the way in which a company's organisation design will be constituted is technology. Not only does technology exert an effect on changes within the organisation, but it also causes changes in the entire society, which left its mark on certain social epochs. According to Warnecke, the term technology was first used in 1790 by Johann Beckmann. [Warnecke, 1993] Since then, the four great industrial revolutions, pertaining to specific technological breakthroughs, have affected humankind. The First Industrial Revolution is associated with the transition from manual production to steam power in the second half of the 18th century. The Second Industrial Revolution began with internal-combustion engine manufacturing in 1892 , while the Third Industrial Revolution started with the development of microprocessors in the $1960 \mathrm{~s}$ and 1970s. The Fourth Industrial Revolution, illustrating the time we are living in, entails the application of biometric payment, trading of solar energy, the process of desalination, the application of artificial intelligence, the Internet of Intelligent Things, the Human Cell Atlas, selfdriving cars, smart clothes, smart homes and biotechnology. [Đorđević et al., 2018]

Out of many definitions of technology, its broadest conception is based on the idea that technology subsumes knowledge, skills, equipment, machinery, techniques and activities by which ideas, information, resources and materials are transformed into products or services. The growing use of technology was accompanied by early empirical studies dealing with the impact of technology on organisation design. These studies include well-known research of Woodward, Perow and Thompson. The research of Woodward demonstrated that ever-growing technol- 
Kahrović E. et al., Organisation Design and the Role of ICT: Negative Effects of Working from Home During the Corona Virus Pandemic

ogy requires the characteristics of organic structure, [Woodward, 1965] Perow showed that technology affects decentralisation, independence, coordination of activities, [Perow, 1967] whereas Thompson underlined the impact of technology on coordination mechanisms through the technological interdependence perspective. [Thompson, 1967]

Information and communication technology (ICT), being one of the major determinants of the present day, represents a body of resources for collecting, processing and transmitting information aimed at supporting business operations of a company. What speaks in favour of a wider and wider ICT application in businesses is the fact that until recently the management could ignore the decision to introduce and implement ICT, whereas nowadays it would be impossible. More precisely, until the 1980s, the primary role of technology entailed the existent business process automation, as well as their faster execution, while in the last forty years, the impact of ICT can be seen in the creation of new forms of organisation design, such as the network organisation, [Miles \& Snow, 1986] hybrid organisation, [Borys \& Jemison, 1989] postmodern organisation, [Clegg, 1990] learning organisation, [Senge, 1990] shamrock organisation, [Handy, 1991] virtual organisation, [Davidow, 1992] intelligent enterprise [Quinn, 1992] hypertext organisation, [Nonaka \& Takeuchi, 1995] ambidextrous organisation, [Tushman \& O'Reilly, 1996] born global [Madsen \& Servais, 1997], modular organisation, [Galunic \& Eisenhardt, 2001] innovation-form organisation [Miles et al., 2009], and so on. New organisational forms are called information-age organisations with a good reason since hardly any modern organisation may be successful without being informationised. [Petković et al., 2014])

The basic characteristic of almost every new organisational form is exhibited in the fact that managers and employees conduct the largest portion of activities at home. Special importance is given to the concept of the so-called virtual organisation, which has been placed at the forefront lately due to ICT that played a pivotal role and made it the $21^{\text {st }}$ century organisation. Although it does not question the functioning of the formal organisational structure, the virtual organisation will yet change many things in the organisation of business entities in the future. Job descriptions will be vague, and work will mainly be carried out in teams. Employees will communicate via mobile phones with their customers and suppliers more often than with their work colleagues, 
and the most difficult thing will involve dealing with uncertainty and risks of a virtual organisation, where changes are becoming a constant. There are, however, many advantages of virtual organisations. Among many, they can be visible in the following: [Daft, 2015; Galbraith, 2012; Sikavica, 2011] they enable even small organisations to have talented workers and resources from all round the world at their disposal; they secure economies of scale without any larger investment in companies, machinery or distribution; they allow organisations to be completely flexible about and highly responsive to changing needs; they lead to reduced administrative costs; they enable successful coordination and communication, regardless of the distance and time zones; they make management simpler. Nonetheless, besides all the stated advantages, there are numerous disadvantages of virtual organisations. These drawbacks mainly reflect employees who formally work with them, but the greatest portion of their work is conducted from home, which is the topic of our considerations below.

\section{The effects of working from home during the coronavirus pandemic}

At present, in the coronavirus pandemic that befell the entire world in 2020, with over 105 million people infected and almost 2395405 dead so far, the workfrom-home concept has been widely advocated to suppress the spread of the virus. This has been a topical issue that many authors addressed, such as the paper of Dingel and Neiman entitled "How many jobs can be done at home?" [Dingel \& Neiman, 2020], that of Gottlieb, Grobovšek and Poschke, "Working from home across countries", [Gottlieb et al., 2020] and among others, Hensvik, Le Barbanchon and Rathelot's, "Which Jobs Are Done from Home? Evidence from the American Time Use Survey". [Hensvik et al., 2020] Certain drawbacks of ICT use in working from home have arisen under these conditions. Accordingly, the following outcomes embody the attributes of principle disadvantages of ICT with regard to working conditions: negative psychological effects, anxiety disorders, health issues, job loss, decreased efficiency, and reduced satisfaction of the employees.

Negative psychological effects. People working from home are often concerned that they are undervalued and disregarded, i.e. that if they are "out of sight", they are "out of mind", as McCloskey and Igbaria underlined in their research in 2003. Numerous studies investigating employees working from home have stressed some of 
Kahrović E. et al., Organisation Design and the Role of ICT: Negative Effects of Working from Home During the Corona Virus Pandemic

the most prominent negative feelings that these employees face. First of all, those are feelings of alienation, underestimation, disrespect, exclusion from important decision-making processes, feelings that their opinion is not valued, together with experiencing difficulty in keeping up with the changes within their companies and not being able to receive some feedback in real time. Many companies occassionally call mandatory meetings in order to prevent the occurrence of the said negative effects. At these meetings, employees exchange their experiences, discuss the set goals and tasks, develop a sense of community and pursue the common goal. [Lukić, 2014]

Anxiety disorders are to do with employees' frustration because of their inability to keep up with an enormous amount of information that they encounter due to ICT use. The human brain has the capacity for memory storage, information processing and exploiting the information - psychologists contend that individuals cannot work with more than 5-9 pieces of information at the same time. Computers and ICT have increased the power of information processing, thereby enabling organisations to overcome the issue of the human limited mind, [Ulwick, 1999] but they have also led to anxiety due to information overload coming from various social networks, smartphones, blogs, emails. As a result of information overload, different health issues may arise, such as insomnia, headache, poor concentration.

The use of computers in everyday work activities may bring about certain health issues. One of the most dominant illnesses detected lately results from repeating the very same movements on the keyboard and mouse, which causes tension in the neck and shoulders, joint pain, and strain on the tendons (cf. Repetitive Stress Injury - RSI). In everyday life, the most common occupational illness is carpal tunnel syndrome (CTS), a medical condition caused by thickening from the lining of irritated tendons connecting the forearm and hand due to constant use of the keyboard and mouse. [Turban et al., 2003] Besides this occupational illness, eye strain caused by computer and smartphone use is very common (cf. Computer Vision Syndrome - CVS). It is believed that eye strain, whose symptoms are blurred vision, dry, irritated eyes and headache, affects over $90 \%$ of people who spend three or more hours per day on their computers. [Lukić, 2014]

ICT use may also result in job loss, [Dutton, 2005] which has been the greatest fear of some employees, who are worried that they might 
lose their job due to automation of certain jobs. On the other hand, workplace stress may occur due to ignorance and inadequate training in working with new technologies, especially in older generations who encounter new technologies for the first time. What is more, employees whose job description includes ICT work are beginning to feel the symptoms of digital taylorism since they are aware that their managers may constantly observe and monitor them via emails, phones, logs, computer files. [Stanford, 2005]

It has also been determined that ICT use for private needs during office hours may lead to decreased efficiency of the employees [Caplan, 2006]. However, efforts made to rectify this problem through limiting or cancelling access to certain ICT segments (particularly private emails and social networks) may produce reduced satisfaction of the employees. [Cox et al., 2005] There are instances when employees fail to set a clear boundary between their working hours and private life, thus becoming constantly available to their superiors, which may result in work-related burnout in the long run. Consequently, some companies cancel access to professional emails and phones to their employees after office hours. All the above mentioned and presented negative effects of ICT bring new challenges and set new tasks for human resource management (HRM).

\section{Conclusion}

Before the transition to working from home occurs, employers need to decide whether working from home suits their business activities. If they do, they need to consult with their employees in order to make the following happen: to provide suitable equipment, technology and training is of crucial importance for establishing contacts with the colleagues and the company itself; both managers and employees need to be explained what they are expected to do in terms of work performance and working conditions; employees are allowed to organise their own time so that they may work within certain time frame, at a place convenient for them, thus being more productive; a risk assessment has been conducted to identify potential safety and health risks, reasonable preventive measures have been taken with regard to working from home if it includes (i) manual work, (ii) hazards and/or risks, (iii) electrical safety, and the following variables have also been taken into consideration: (iv) general factors such as noise, having first-aid kits and/or fire exits etc; a risk assessment of potential risks that an employee has reported has been carried out, including any specific risks con- 
Kahrovic E. et al., Organisation Design and the Role of ICT: Negative Effects of Working from Home During the CoronaVirus Pandemic

nected with working from home (e.g. domestic violence); employee's duties have been arranged in terms of the company's policies, such as working hours, confidentiality, and security practices while working from home; it has been determined that the premises wherein employees work are adequate; it has been determined how the employer may contact their employees and conversely, and whether communication channels have been developed.

\section{Reference}

Borys, B. \& Jemison, D. (1989). Hybrid arrangements as strategic alliances: theoretical issues in organizational combinations. Academy of Management $\mathrm{Re}^{-}$ view, 234-249.

Burton, R. (2013). The future of organization design, an interpretative synthesis in three themes. Journal of Organization Design, 42-44.

Burton, R., DeSanctis, G. \& Obel, B. (2006). Organizational design, a step by step approach. New York: Cambridge University Press.

Caplan, S. (2006). Problematic internet use in the workplace. In M. Anadarajan, T. Teo, \& C. Simmers, The Internet and Workplace Transformation (pp. 63-79). New York: Armonk.
Chandler, A. (1962). Strategy and Structure: Chapters in the History of the Industrial Enterprise, Cambridge: The M.I.T. Press.

Clegg, S. (1990). Modern Organizations: Organization Studies in the Postmodern World. London: Sage.

Cox, S., Goette, T. \& Young, D. (2005). Workplace Surveillance and Employee Privacy: Implementing an Effective Computer Use Policy. Communications of the International Information Management Association, 57-65.

Daft, R. (2015). Organization Theory and Design. Cengage Learning.

Davidow, W. (1992). The virtual corporation. Structuring and revitalizing the corporation for the $21^{\text {st }}$ century. New York: Harper Business.

Dingel, J. \& Neiman, B. (2020). How Many Jobs Can be Done at Home? National Bureau of Economic Research.

Đorđević, N., Kahrović, E., Mirčić, D. \& Beara, M. (2018). Biopreduzetničke inovacije kao osnova za pokretanje novih poslovnih poduhvata. Naučne publiкасije Državnog univerziteta $u$ NovomPazaru, Serija B: Društvene \& humanističke nauke, $1(1), 14-27$. 
Dutton, W. (2005). Continuity or Transformation? Social and Technical Perspectives on Information and Communication Technologies. In B. Dutton, K. O'Callaghan, \& A. Wyckoff, Transforming Enterprise, The Economic and Social Implications of Information Technology (pp. 13-24). Cambridge: The MIT Press.

Galbraith, J. (2012). The evolution of enterprise organization designs. Journal of Organization Design, 1-13.

Galunic, D. \& Eisenhardt, M. (2001). Architectural Innovation and Modular Corporate Forms. Academy of Management Journal, 1229-1250.

Gottlieb, C., Grobovšek, J. \& Poschke, M. (2020). Working from home across. Covid Economics.

Handy, C. (1991). The Age of Unreason. Boston: Harvard Business Review.

Hensvik, L., Le Barbanchon, T. \& Rathelot, R. (2020). Which Jobs Are Done from Home? Evidence from the American Time Use Survey, Institute of Labor Economics.

Irwin, C. \& Cichocki, P. (2011). Organization Design, A Guide to Building Effective Organizations. London: KoganPage.
Janićijević, N., Bogićević Milikić, B., Petković, M. \& Aleksić Mirić, A. (2019). Organizacija. Beograd: Ekonomski fakultet $u$ Beogradu.

Katz, D. \& Kahn, R. (1978). The Social Psychology of Organizations. Wiley.

Lawrence, P. \& Lorsch, J. (1967). Differentiation and Integration in Complex Organizations. Administrative Science Quarterly, $1-47$.

Lukić, J. (2014). The role of information and communication technology in a virtual organization: Challenges for virtual employees. First International Academic Conference Places and Technologies (pp. 1098-1105). Belgrade: Faculty of Architecture.

Madsen, T. \& Servais, P. (1997). The Internationalization of Born Globals: an Evolutionary Process. International Business Review, 561-583.

McCloskey, D. \& Igbaria, M. (2003). Does "out of sight" mean "out of mind"? An empirical investigation of the career advancement prospects of virtual workers. Information Resources Management Journal, 19-34. 
Kahrovic E. et al., Organisation Design and the Role of ICT: Negative Effects of Working from Home During the CoronaVirus Pandemic

Miles, R. \& Snow, C. (1986). Network organizations: New concepts for new forms. California Management Review, 62-73.

Miles, R., Miles, G., Snow, C., Blomqvist, K. \& Rocha, H. (2009). The I-form organization. California Management Review, 59-74.

Mintzberg, H. (1979). The structuring of organizations. Englewood Cliffs: Prentice Hall.

Nonaka, I. \& Takeuchi, H. (1995). The Knowledge-creating Company: How Japanese Companies Create the Dynamics of Innovation. Oxford: University Press.

Perrow, C. (1967). A framework for the comparative analysis of organizations. American Sociological Review, 194-208.

Petković, M., Orelj, A. \& Lukić, J. (2014). Managing employees in a virtual enterprise. International Scientific Conference Impact of the Internet on Business Activities in Serbia and Worldwide (pp. 227-232). Belgrade: Singidunum University.

Pugh, D. \& Hickson, D. (1993). Great Writers on Organizations. Dartmouth: Aldershot.

Puranam, P. (2012). A Future of the Science of Organization Design. Journal of Organization Design, 18-19.
Quinn, J. (1992). The Intelligent Enterprise a New Paradigm. Academy of Management, 48-63.

Senge, P. (1990). The Fifth Discipline. The art and practice of the learning organization. London: Random House.

Sikavica, P. (2011). Organizacija. Zagreb: Školska knjiga.

Stanford, N. (2005). Organization Desing: The Collaborative Approach. Oxford: Elsevier Butterworth-Heineman.

Thompson, J. (1967). Organizations in Action. New York: McGrawHill.

Turban, E., McLean, E. \& Wetherbe, J. (2003). Informaciona tehnologija za menadžment, transformisanje poslovanja u digitalnu ekonomiju. Beograd: Zavod za udžbenike i nastavna sredstva.

Tushman, M. \& O'Reilly, C. (1996). Ambidextrous organizations: Managing evolutionary and revolutionary change. California Management Review, 8-30.

Ulwick, A. (1999). Business Strategy Formulation: Theory, Process, and the Intellectual Revolution. London: Quorum Books. 
Warnecke, H. (1993). The Fractal Woodward, J. (1965). Industrial Company. Berlin: Springer- Organization: Theory and PracVerlag. tice. London: Oxford University Press.

\footnotetext{
${ }^{1}$ https://orcid.org/0000-0002-0892-4908

2 https://orcid.org/0000-0001-5090-193X
} 


\title{
ORGANIZACIONI DIZAJN I ULOGA $I K T$. NEGATIVNI EFEKTI RADA OD KUĆE U USLOVIMA PANDEMIJE VIRUSA KORONA
}

\author{
Ernad Kahrović ${ }^{1}$, Emina S. Kahrović ${ }^{2}$ \\ 1, 2 Departman za ekonomske nauke, Državni univerzitet \\ u Novom Pazaru
}

Korespondencija: ekahrovic@np.ac.rs ${ }^{1}$

Rezime: Osnovni cilj ovog rada jeste da ukaže na ulogu i značaj organizacionog dizajna kao sredstva za implementaciju strategije preduzeća, kao i na dominantan uticaj tehnologije na oblikovanje dizajna. Naime, sa napretkom savremenih informacionokomunikacionih tehnologija (IKT) došlo je do pojave novih organizacionih formi, koje omogućavaju menadžmentu preduzeća i zaposlenima da dobar deo posla obavljaju od kuće. Ovaj rad upravo je posvećen uticaju tehnologije na stvaranje novih formi dizajna, među kojima posebno mesto zauzima virtuelna organizacija. Autori rada ističu činjenicu da je među mnogim promenama u ritmu života koje je donela pandemija virusa korona, jedna od najkrupnijih jeste prelazak na rad od kuće, pa se u radu ističu negativni efekti istog, a koji se odnose na negativne psihološke uticaje, anksiozne poremećaje, zdravstvene probleme, gubitak posla, smanjenje efikasnosti i smanjenje zadovoljstva zaposlenih.

Ključne reči: organizacioni dizajn, informaciona tehnologija, virus korona. 